DE DE GRUYTER OPEN
ACTA ENVIRONMENTALICA

UNIVERSITATIS COMENIANAE (BRATISLAVA)

ISSN 1339-9802 (online)

\title{
CONTENTS OF POTENTIALLY TOXIC METALS AND MAGNETIC SUSCEPTIBILITY OF SOILS ALONG A RURAL - URBAN - RURAL GRADIENT IN BRATISLAVA CITY (SLOVAKIA)
}

\author{
Lucia Lachká, Edgar Hiller \& Ondrej Ďurža \\ Department of Geochemistry, Faculty of Natural Sciences, Comenius University in Bratislava, \\ Mlynská dolina, Ilkovičova 6, 84215 Bratislava, Slovak Republic \\ Corresponding author: Edgar Hiller (e-mail: hiller@fns.uniba.sk)
}

\begin{abstract}
The concentrations of potentially toxic metals ( $\mathrm{As}, \mathrm{Cd}, \mathrm{Cu}, \mathrm{Hg}, \mathrm{Pb}, \mathrm{Zn}$ and $\mathrm{Fe}$ ) and the values of magnetic susceptibility in surface soils were measured along NW-SE gradient in Bratislava city (rural - urban - rural soils). The results indicate that both the contents of potentially toxic metals (PTMs) and the values of magnetic susceptibility decrease with increasing distance from the city centre in both directions. Urban soils are enriched mainly in $\mathrm{Cu}, \mathrm{Hg}, \mathrm{Pb}$ and $\mathrm{Zn}$. Their elevated concentrations in soils within the city are due to accumulation from anthropogenic activities. There was a statistically significant and positive correlation between the mean values of Tomlinson pollution load index (PLI) and the mean values of magnetic susceptibility in soil samples. This correlation shows that the monitoring of magnetic properties of soils can be used as a rapid and non-destructive tool for the effective determination of environmental pollution in urbanized regions affected by anthropogenic activities.
\end{abstract}

Key words: potentially toxic metals; magnetic susceptibility; urban and rural soil; pollution

Recommended form of citation: Lachká, L., Hiller, E. \& Durža, O., 2016. Contents of Potentially Toxic Metals and Magnetic Susceptibility of Soils Along a Rural - Urban - Rural Gradient in Bratislava City (Slovakia). Acta Environ. Univ. Comenianae (Bratislava). 24(1): 25-37.

DOI: 10.1515/aeuc-2016-0004

\section{INTRODUCTION}

Potentially toxic metals (PTMs) are occurring commonly in soils but in general, their contents are increased in the urban environment due to anthropogenic activities. Two classes of anthropogenic sources of PTMs can be distinguished: (i) point sources that occur in the vicinity of pollution site, and (ii) diffuse sources, when PTMs are dispersed in the environment farther from pollution sources (ČURLÍK \& JURKOVIČ 2012).

ZHU \& CARREIRO (2004) documented that nitrogen mineralization and nitrification were significantly higher in urbanized regions than in rural regions, whereas total content of $\mathrm{P}$ was lower in urban soils than in rural soils. WAGROWSKI \& HITES (1997) found that concentrations of polycyclic 
aromatic hydrocarbons (PAHs) in soils exhibited a strong dependence on the urban - rural gradient. Similar trends in PAH concentrations in soils were observed also by HILLER et al. (2015). These changes are attributed to the traffic and industrial activities that are dependent on the urbanization level.

Elevated concentrations of PTMs in urban environments can represent an important input source to the human body through the inhalation of soil dust, and especially for children, through the soil ingestion or dermal contact with soil. Several PTMs have adverse health effects, mostly for children, because of their low body weight and developing nervous system (LJUNG et al. 2006).

Measurements of magnetic susceptibility of surface soil horizons were successfully used for the mapping of anthropogenic pollution level in the vicinity of thermal power plants, cement factories or metallurgical plants (ĎURŽA 1999; PETROVSKÝ et al. 2000; YANG et al. 2012). The mapping of magnetic properties at wide regional scale was performed for different regions in many countries, e.g. United Kingdom (BLundELL et al. 2009), Germany (SPITERI et al. 2005) and Argentina (CHAPARRO et al. 2008). Soil magnetic measurements can be also used in studies of urban soils (SHILTON et al. 2005; LU et al. 2011), surface sediments (BRANDAU \& URBAT 2000; MiLIČKA et al. 2002) or in soil investigations of paleo soils and loesses (ĎURŽA \& DLAPA 2009; ORGEIRA et al. 2011).

Previous research has shown that environmental magnetic methods can be used not only for the identification of pollution sources but also for the approximate determination and characterization of the pollution level in urban soils (SCHMIDT et al. 2005; SPITERI et al. 2005; D'EMILIO et al. 2007). Measurements of magnetic parameters were successfully used as a rapid method for the identification of sources of environmental pollution and the mapping of spatial and seasonal distribution of urban areas (PETROVSKÝ et al. 2000; MAHER et al. 2008).

MIKL'AJEV \& KUDRJAVCEV (1982) recommended soil magnetic measurements to be used as a proxy method, which allows to identify regions with "elevated geochemical anomalies", to reduce considerably the volume of laboratory works and to change flexibly the mapping methodology. An advantage of the magnetic measurement for the identification of environmental pollution is that it is simple, rapid and non-destructive, allowing it to become controlling, monitoring and cheap tool for precise chemical analyses.

The main aim of this work was: (1) to determine the concentration of selected PTMs (As, $\mathrm{Cd}, \mathrm{Cu}$, $\mathrm{Hg}, \mathrm{Pb}$ and $\mathrm{Zn}$ ) and magnetic properties of surface soils collected from a depth of $0-10 \mathrm{~cm}$ along NW-SE gradient in Bratislava city (rural - urban - rural soils) and (2) to provide scientific base for the pollution control and consecutive monitoring of urban soils for PTMs.

\section{Soil magnetic susceptibility}

The most magnetic horizon in a soil profile is the humus horizon, in which iron and other transition elements are in ferrimagnetic state (MIKLAJEV \& ŽOGOLEV 1990). Almost all soils contain two strongly magnetic minerals: magnetite (including (titano)magnetites) and maghemite (including (titano)maghemites). Ferrimagnetic particles of iron oxides in ashes, forming during high-temperature combustion of fossil fuels, are the most important source of anthropogenic ferrimagnetic materials found in surface soil horizons (FLANDERS 1994). In addition to magnetite, pyrite is the main source of ferrimagnetic materials in coal, where its content reaches up to $15 \mathrm{wt} \%$ of the total inorganic fraction present in bituminous coal (MAGIERA \& STRZYSZCZ 2000). Pyrite and other iron sulphides are oxidized during coal combustion. Sulphur is released in a gaseous phase, whereas iron is incorporated into ferrimagnetic minerals that are emitted to the atmosphere with other dust particles. Anthropogenic ferrimagnetic materials are transported as dust and aerosols to different distances, and finally deposited on the soil surface. Anthropogenic ferrimagnetic particles are characterized by specific 
morphology (mostly as spheres with the size ranging from unit $\mu \mathrm{m}$ up to hundred $\mu \mathrm{m}$ ). Their content in ashes is relatively high (approximately $10 \mathrm{wt} \%$ ) and magnetic measurements indicate high values of magnetic susceptibility.

The deposition of atmospheric particulates represents one of the most important contribution to the total environmental load of soils. In addition to gaseous phase, potentially toxic metals are adsorbed on solid particulates that consist mainly of blown soil particles and coal particles. According to PETROVSKÝ et al. (2000), these particulates are generally higher than $5 \mu \mathrm{m}$ but blown clayey particles have smaller dimensions. The mean size of atmospheric particulates ranges from $0.01 \mu \mathrm{m}$ to $20 \mu \mathrm{m}$.

\section{Urban soils}

Urban soils are those that occur in urbanized, industrial, traffic, mining and military regions (SOBOCKÁ et al. 2007). Almost $85 \%$ of European population lives in urbanized regions. A typical environmental factor acting in urbanized regions is the higher level of pollution in cities than in ambient rural land. It is due to environmental pollution caused by emissions from traffic and industries, and wastes of industrial, municipal and construction origin.

Urban soils are important indicators of the urban environment and serve as a primary sink for chemical pollutants because anthropogenic PTMs and organic pollutants are normally deposited on the soil surface. The accumulation of pollutants in urban soils leads to degradation of soil quality and poses also a health risk for humans and ecosystems (CHEN 2007; ĎURŽA et al. 2013).

Anthropic soils are predominant soil group (they cover $33.5 \%$ of the total area) in the region of Bratislava. Initial soils are the second important soil group (they cover 26\%), among which fluvisols are the most abundant. Another soil groups in the region of Bratislava are molic soils (21\%), occurring in plain parts of the Danubian Lowland, and brown soils (16\%) with the predominant occurrence in the Malé Karpaty Mts. Rendzinas (2\%) are found in a wider area of Devínska Kobyla and Záhorská Bystrica. Regarding the soil type, the most abundant are fluvisols (21.8\%) and anthrosols (19.1\%), followed by cambisols (16.3\%), cultizems (14.4\%) and chernozems (14.0\%) (SOBOCKÁ et al. 2007).

\section{Study area}

Bratislava city is situated in SW Slovakia and covers three physico-geographical units (MAZÚR \& LUKNIŠ 1980): the Malé Karpaty Mts., the Záhorská and Danubian Lowlands. The climate of the Bratislava region is gently warm with mild winter and warm summer. The mean annual temperature is $10.3{ }^{\circ} \mathrm{C}$. The annual precipitation varies between 500 and $650 \mathrm{~mm}$, and north-western winds are prevailing (SOBOCKÁ et al. 2007). The total area of the city is $367.6 \mathrm{~km}^{2}$ and almost 500,000 inhabitants live permanently in the city. Important sources of environmental pollution in Bratislava city are considered chemical, energetic, engineering, building and glassware industries, as well as municipal waste incinerator and traffic. Another significant source of atmospheric pollution in the city is secondary dust nuisance, which depends on the meteorological conditions, field and agricultural works and the type of surface (WWW.ENVIROPORTAL.SK).

SoBockÁ et al. (2007) divided the soils of Bratislava city into ten regions. In this work, the investigated rural - urban - rural soil gradient along the city included six out of ten regions: the Záhorská Lowland, Devínska Kobyla, Malé Karpaty Mts. and its foothill, Karloveská priekopa, Podunajská rovina and built-up area.

Considerable part of the Záhorská Lowland is formed by Neogene sediments that are covered by quaternary sediments. The most widespread soil types are phaeozems, mainly cultizemic. They have the molic Amč-horizon with oxidation signs (aggregates, Fe and Mn nodules), however, without gleyic reduction horizon. 
Devínska Kobyla is formed by Mesozoic sedimentary complex, which consists of marls, dolomites, limestones and sandstones together with marlaceous limestones and schists. These rocks are parent substrate of rendzinas and pararendzinas that cover almost the whole protected region. Modal luvisols originated from loess occur also in some parts of Devínska Kobyla.

The soils of the Malé Karpaty Mts. come from crystalline rocks, mainly schists, diorites, pegmatites and granitic rocks of Bratislava's type. Modal cambisols are predominant soil types up to 500 metres above sea level. The soils have developed metamorphic cambic $\mathrm{Bv}$-horizon formed by brunification process with the occurrence of metal oxyhydroxides. There are also subtypes of cambisols like stagno-gleyic and luvizemic cambisols in lower parts of the Malé Karpaty Mts.

River terraces of Karloveská priekopa towards the Mlynská dolina Valley are covered by quaternary aeolian sediments (sandy and loamy loesses). The residues of chernozems with the dark mollic A-horizon and carbonate content higher than $0.30 \mathrm{wt} \%$ can be found in the region.

Sarmatian-Pannonian Neogene sediments of the Podunajská rovina are covered by a complex of Pleistocene and Holocene fluvial sediments represented by sands, gravels, clays and sandstones with small calcareous and manganese aggregates. A large area of Bratislava city is occupied by elevated plain of the Danubian Lowland with no direct contact with groundwater table. Cultizemic chernozems are predominant soil group of the south-western and south-eastern parts of the region.

Built-up area of Bratislava city is characterized by soils strongly affected by anthropogenic activities. The soils are components of ornamental gardens, street alleys, recreational sites, child and school playgrounds, cemeteries, urban parks, etc. The main soil groups of built-up areas are cultizems and anthrosols. Cultizems are soils with strongly modified surface horizon (more than $30 \mathrm{~cm}$ ) and the nature of these soils can be identified according to the residual native diagnostic horizon.

Soils of new built-up residential areas, historical centre, commercial or industrial zones are considered as anthrosols, i.e. the soils modified by human interventions with the anthrozemic Adhorizon, which was formed by transported anthropogenic materials of different origin. All subtypes of anthrosols may be found in Bratislava city but the most abundant is the initial anthrosol with $1-10$ $\mathrm{cm}$ thick Ad-horizon and organic carbon content of $0.30 \mathrm{wt} \%$ and more.

In this work, a NW-SE gradient along Bratislava city was investigated, with rural soils in NW part of the gradient, urban soils in central parts, and rural soils in SE part of the gradient. The following nine zones were selected (Fig. 1):

- Zones I and IX (rural area) - zone I is situated on NW margin of Bratislava city, i.e. NW from Devínska Kobyla. It reaches the Záhorská nížina Lowland. Zone IX is on SE margin of the city and reaches the Danubian Lowland. The soils in both zones are agriculturally managed, and therefore less affected by anthropogenic factors.

- Zones III, IV, VII and VIII (built-up area) - zones III and IV are situated NW from the city centre. Zone III is Dúbravka and zone IV is Karlova Ves up to the Mlynská dolina Valley. Zones VII and VIII are located SE from the city centre. They are bordered by the Bajkalská Street and the Little Danube Channel, including Podunajské Biskupice. These zones are used mainly for housing and agricultural soils of the zones serve for gardening. The soils are relatively less impacted by anthropogenic activities.

- Zone V (historical city centre) - this zone is characterized by high population density with more than 2000 years old history of settlement, industrial and commercial utilization, as well as by dense traffic. It is bordered by the Mlynská dolina Valley and the Štefánikova Street.

- Zone VI (wider city centre) - the zone has 50-100 years old history of settlement, industrial and commercial utilization and suffers from dense traffic for the last fifteen years. This zone is bordered by the Štefánikova and Bajkalská Streets. 
- Zone II (vicinity of technical glassworks) - zone II is located close to technical glassworks (SZTS), where leaded glass was produced.

All selected zones are approximately $3 \mathrm{~km}$ long, with the exception of zone II, which is shorter - vicinity of SZTS (Fig. 1).

\section{MATERIAL AND METHODS}

\section{Measurement of soil magnetic susceptibility}

Firstly, plant cover of soil sampling sites $(1 \times 1 \mathrm{~m})$ was cleared away, and then the sampling sites, if necessary, were adapted in a manner not to be free air space between the instrument and the soil surface, which could distort the measured values of soil magnetic susceptibility.

Magnetic susceptibility values were determined using a kappameter KT-5. The basic part of an instrument is $10 \mathrm{kHz}$ oscillator inductively coupled with a flat exploring coil in a measuring part of the instrument. The frequency of oscillator is measured by coil placed at the distance higher than $30 \mathrm{~cm}$ from the soil surface (free space measuring) and by coil enclosed to the soil surface. The magnetic susceptibility is determined by microprocessor on the basis of difference between frequencies and numerically displayed. The objects at a distance of $30 \mathrm{~cm}$ from the instrument may affect the measured values. The measurement uncertainty is $\pm 10 \%$.

\section{Soil sampling and laboratory analysis}

Soil samples were collected along NW-SE gradient in Bratislava city from different parts of the city, representing rural soils in NW and SE margins of the gradient and urban soils in central part of the gradient. Totally, 57 soil samples were used in this work and the sampling sites are shown in Fig. 1. After clearing the plant cover and measuring the magnetic susceptibility, approximately the first $10 \mathrm{~cm}$ of surface soil was taken. Four soil samples were collected from zone I, 5 soil samples from zone II, 6 soil samples from zone III, 3 soil samples from zone IV, 7 soil samples from zone V, 12 soil samples from zone VI, 9 soil samples from zone VII, 7 soil samples from zone VIII and there were 4 soil samples from zone IX.

Before analyses, the soil samples were dried at room temperature, gently disaggregated and passed through a $2 \mathrm{~mm}$ sieve. The soils samples were analysed for the occurrence of $\mathrm{As}, \mathrm{Cd}, \mathrm{Cu}, \mathrm{Fe}, \mathrm{Pb}$ and $\mathrm{Zn}$ after total digestion using an acid mixture of $\mathrm{HNO}_{3}, \mathrm{HCl}$ and $\mathrm{HF}$. Only exception was $\mathrm{Hg}$, which was determined directly on the solid samples using a Mercury Analyzer AMA 254. Concentrations of other metals and As in the extracts were measured by inductively coupled plasma-atomic emission spectrometry (ICP-AES; Vista AX, Varian) and atomic absorption spectrometry (AAS; Varian SpectrAA 220) equipped with a hydride generation system (VGA 76), respectively. All chemical analyses were done in accredited testing laboratories EL Ltd. in the city of Spišská Nová Ves.

\section{RESULTS AND DISCUSSION}

Fig. 2 shows the changes in concentrations of PTMs ( $\mathrm{As}, \mathrm{Cd}, \mathrm{Cu}, \mathrm{Hg}, \mathrm{Pb}, \mathrm{Zn}$ and $\mathrm{Fe}$ ) in the studied gradient. The concentrations of PTMs indicate a clear trend in the gradient of rural - urban - rural soils. As can be seen from Fig. 2, mainly the contents of typical "urban" metals $\mathrm{Cu}, \mathrm{Hg}, \mathrm{Pb}$ and $\mathrm{Zn}$ in soil decrease with increasing distance from the city centre. The soils in the city centre (zones $\mathrm{V}$ and VI) exhibit significantly elevated concentrations of PTMs when compared to the soils from rural areas (zones I and IX). The same trend is obtained for soil magnetic susceptibility values (Fig. 2). Urban soils are an important sink for many PTMs, originating from different sources, including industrial wastes, emissions from motor vehicles, wastes from coal combustion and other anthropogenic 
activities. Elevated concentrations of PTMs, such as $\mathrm{Cd}, \mathrm{Cu}, \mathrm{Pb}$ and $\mathrm{Zn}$ in urban surface soils are an evidence of their accumulation from anthropogenic activities. Similar trends in PTM concentrations in soils across cities were obtained also by other authors (WONG et al. 2004; LU et al. 2009) who documented that concentrations of inorganic and organic contaminants within a given city were lower in soils from rural regions than in soils from highly urbanized regions.

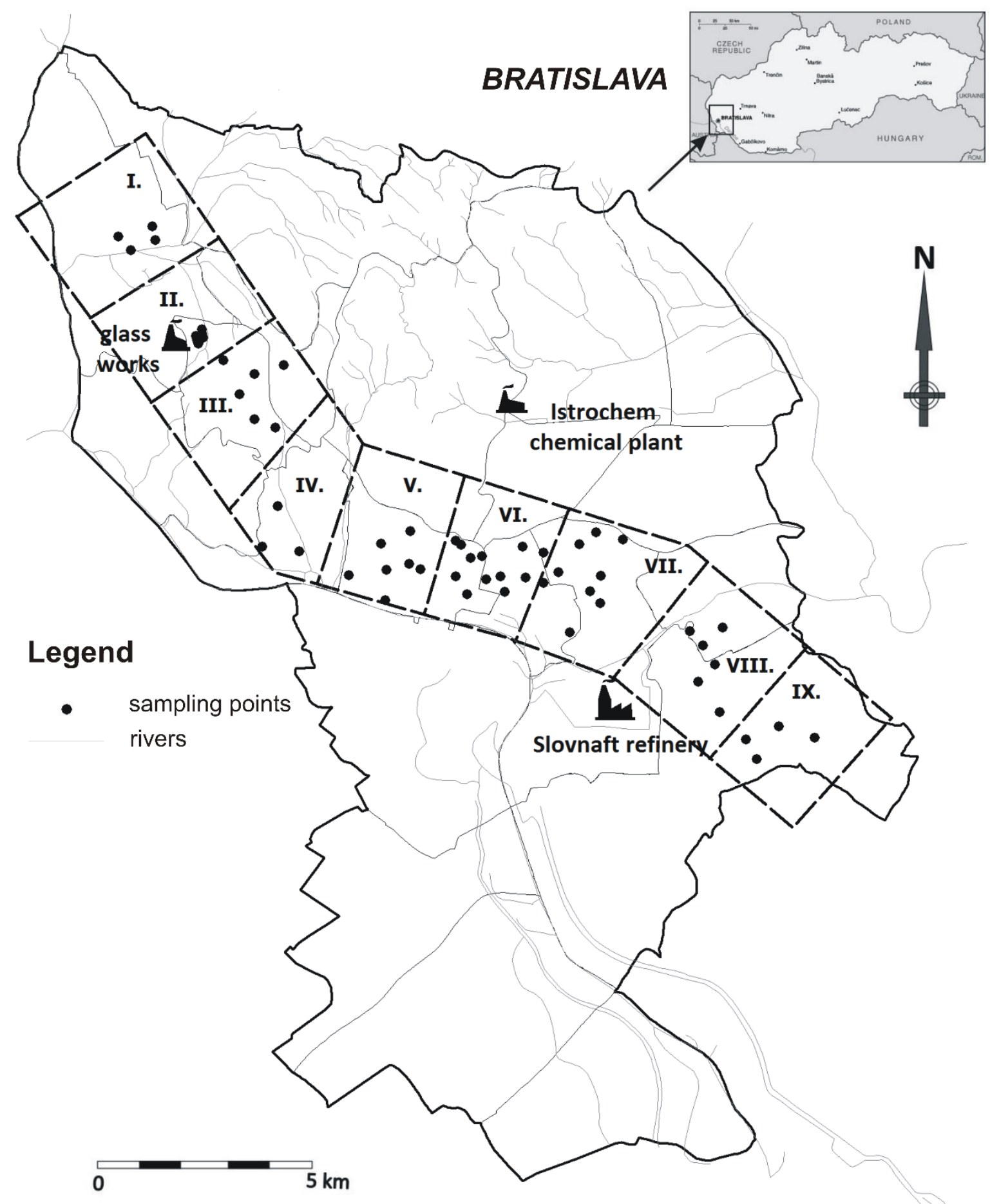

Fig. 1: Location of the soil sampling sites and studied zones along the gradient rural - urban - rural soils in Bratislava city 


\section{NW-SE gradient across Bratislava}
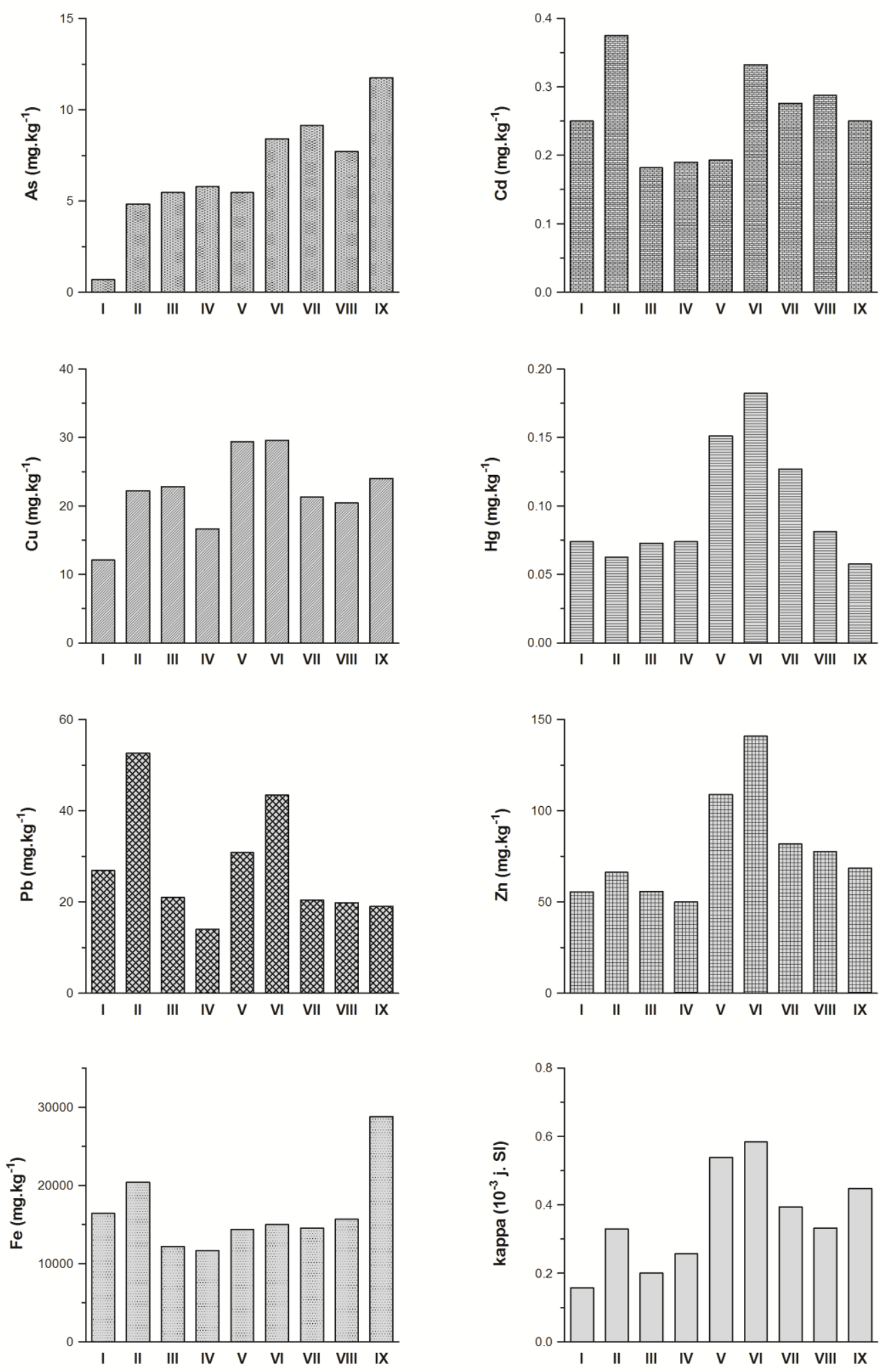

Fig. 2: The effect of distance from the city centre (zones V and VI) on the concentration of potentially toxic metals and the magnetic susceptibility value (kappa) along the gradient rural - urban - rural soils in Bratislava city 
Very interesting are the concentrations of PTMs in soils of zone II, i.e. in the vicinity of technical glassworks, where leaded glass was produced in the past. This is demonstrated by elevated concentrations of $\mathrm{Pb}$ in the soils, as well as $\mathrm{Cd}$ and $\mathrm{Fe}$. The anomaly in the form of increasing concentrations of $\mathrm{Cd}, \mathrm{Pb}$ and $\mathrm{Fe}$ with increasing distance from the city centre was exhibited also by magnetic susceptibility values (Fig. 2). Another anomaly in general trend of decreasing concentrations of PTMs with increasing distance from the city centre (zones V and VI) was observed for Fe and As in zone IX with the highest mean concentrations of both chemical elements in soils among the selected zones (Fig. 2). This may be explained by long-term effects of petrochemical plant Slovnaft and waste incinerator on the pollution of the surrounding environment.

Notable is also the finding that soil contents of various PTMs (e.g. $\mathrm{Cd}, \mathrm{Cu}, \mathrm{Hg}$ and $\mathrm{Zn}$ ) and magnetic susceptibility values are higher at SE end of the gradient across the city than at its NW end. This may be due to prevailing NW winds, meaning that the pollution moves from the city centre towards SE, and also due to different soil textures. Sandy soils occur mainly in NW part of Bratislava city, whereas finer, loamy soils are more common in SE part of the city. It is well-known from previous studies (VADJUNINA \& BABANIN 1972; HANESCH \& SCHOLGER 2005; YANG et al. 2015) that soils with the higher silt content and organic carbon content have usually also higher concentrations of PTMs and values of magnetic susceptibility in comparison to sandy soils.

The change in concentrations of PTMs in soils of different zones across urbanized area can be attributed to the distinct pollution sources and the history of urban land use. Additionally, atmospheric deposition of urban dust, containing elevated concentrations of PTMs, is one of the main sources for the accumulation of toxic metals in urban soils (LI et al. 2001; NG et al. 2003; NORRA \& STUBEN 2003). The effect of urban dust on the soil magnetic susceptibility values was studied at sites monitored for the content of solid particulates $\left(\mathrm{PM}_{10}\right)$ that are freely dispersed in the air (MALOVCOVÁ 2014) (Table 1). Particulate matter $\mathrm{PM}_{10}$ is defined as particles, from which $50 \%$ has an aerodynamic diameter less than $10 \mu \mathrm{m}$. Because of their large surface area, these particles produced by anthropogenic activities are effective adsorbents and accumulators of chemical pollutants like PTMs or organic compounds (e.g. polycyclic aromatic hydrocarbons and polychlorinated biphenyls) (TAN et al. 2006; MENICHINI et al. 2007; MURÁNSZKY et al. 2011).

Tab. 1: Comparison of measured magnetic susceptibility values in the soils at automatic monitoring stations of Slovak Hydrometeorological Institute with the measured air concentrations of PM $_{10}$ particles in 2012

\begin{tabular}{lcc}
\hline Location & kappa & $\mathbf{P M}_{\mathbf{1 0}}$ \\
& $\left(10^{-3} \mathrm{j} . \mathrm{SI}\right)$ & $\left(\mu \mathrm{g} . \mathrm{m}^{-3}\right)$ \\
\hline Jeséniova Street & 0.58 & 25.7 \\
Mamateyova Street & 0.30 & 25.1 \\
Trnavské mýto & 0.87 & 35.6 \\
Kamenné námestie & 0.39 & 25.8 \\
\hline
\end{tabular}

With respect to the low number of monitored sites for the content of $\mathrm{PM}_{10}$ particles, the data in Table 1 are not sufficiently representative, nevertheless, they provide an approximate pattern about possible relationship between the content of $\mathrm{PM}_{10}$ particles and the soil magnetic susceptibility. The relationship between the values of soil magnetic susceptibility and $\mathrm{PM}_{10}$ content in air was significant with Pearson correlation coefficient of 0.90 . Deposition of particulate matter of anthropogenic origin contains a high proportion (usually $5-9 \mathrm{wt} \%$ ) of strongly magnetic particles (ROBERTSON et al. 2003; KAPIČKA et al. 2004).

Trnavské mýto belongs to crossroads with the highest traffic volume, corresponding also to the content of $\mathrm{PM}_{10}$ particles $\left(35.6 \mu \mathrm{g} \cdot \mathrm{m}^{-3}\right)$, which was the highest among the above mentioned monitored 
sites (Table 1). The highest value of soil magnetic susceptibility was determined at the site $\left(0.87 \times 10^{-3}\right.$ j.SI). On the other hand, the lowest content of $\mathrm{PM}_{10}$ particles $\left(25.1 \mu \mathrm{g} \cdot \mathrm{m}^{-3}\right)$ among all stations and also the lowest values of soil magnetic susceptibility $\left(0.30 \times 10^{-3} \mathrm{j}\right.$.SI $)$ were found in Mamateyova Street. A transported sandy soil occurs at the site, which contains only low amounts of PTMs likely due to low adsorption capacity of quartz grains (ALLOWAY 1990). However, at site Jeséniova, clayey soils occur that might have an effect on the higher values of soil magnetic susceptibility $\left(0.58 \times 10^{-3} \mathrm{j} . \mathrm{SI}\right)$ in comparison with $\mathrm{PM}_{10}$ content $\left(25.7 \mu \mathrm{g} . \mathrm{m}^{-3}\right)$. Similar values of $\mathrm{PM}_{10}$ content $\left(25.8 \mu \mathrm{g} . \mathrm{m}^{-3}\right)$ were on Kamenné námestie, where lower values of magnetic susceptibility in soils were recorded $\left(0.39 \times 10^{-3}\right.$ j.SI) than in soils at site Jeséniova.

A complex pollution index, i.e. Tomlinson pollution load index (PLI) was calculated for all seven PTMs investigated in this work to assess the environmental quality of the soils (TOMLINSON et al. 1980). Tomlinson pollution load index is defined as the $n$-th root of ratios between the actual concentration of a metal in soil $\left(\mathrm{C}_{\mathrm{n}}\right)$ and the background concentration of the same metal in soil $\left(\mathrm{B}_{\mathrm{n}}\right)$ $\left(\mathrm{CF}_{\mathrm{n}}=\mathrm{C}_{\mathrm{n}} / \mathrm{B}_{\mathrm{n}}\right)$ :

$$
\mathrm{PLI}=\sqrt[\mathrm{n}]{\mathrm{CF}_{1} \times \mathrm{CF}_{2} \times \ldots \mathrm{CF}_{\mathrm{n}}}
$$

As the geochemical background of PTMs, their mean concentrations in C horizons of soils from Bratislava city were used and they were obtained from the database of Soil Geochemical Atlas of Slovakia (ČURLíK \& ŠEFČ́́K 1999). This pollution index is a measure of the overall toxicity of soil samples and results from the contribution of all seven PTMs. The values of PLI higher than 1.0 indicate deterioration in soil quality. As can be seen from Fig. 3a, there was a significant and positive relationship between the mean values of soil magnetic susceptibility and mean PLI values. The significant correlation (Fig. 3a) with the data shown in Fig. 2 suggest that measurements of magnetic properties in soils can be used as a rapid and cheap tool for the monitoring of soil pollution with potentially toxic elements caused by anthropogenic and industrial activities. The utilization of magnetic susceptibility measurements for tracing of pollution in urban soils with PTMs was also supported by strong correlations of magnetic susceptibility values to the contents of individual PTMs in soils (Table 2). These findings are explained by the fact that PTMs adsorb preferentially on the external surface of ferrimagnetic grains, containing frequently a considerable amount of ferric oxyhydroxides (LU et al. 2008). Magnetic components are admixed with other PTMs. Coexistence of PTMs with magnetic components present in soils can explain elevated concentrations of PTMs in surface soils of urbanized regions along the urban - rural gradient. Observed correlations of PLI values and PTM concentrations with magnetic susceptibility of the soils along NW-SE gradient in Bratislava city are consistent with the results from other cities of different countries in the world, e.g. Hangzhou, Shanghai and Kaifeng cities in China (LU \& BAI 2006; HU et al. 2007; LIU et al. 2016), Beni Mellal city in Morocco (El BAGHDADI et al. 2012), Mexico city (MORTON-BERMEA et al. 2009) or Wien in Austria (SIMON et al. 2013). Additionally, according to the mean values of PLI (Fig. 3b), the environmental quality of the soils is the worst in the city centre (zone V) and wider surrounding of the central zone (zone VI), whereas the soils of NW rural area (zone I) and residential areas (zone III and IV) have much better quality. 
Tab. 2: Pearson correlation coefficients for relationships between soil magnetic susceptibility and soil contents of PTMs

\begin{tabular}{llllllll}
\hline & As & Cd & Cu & Hg & Pb & Zn & Fe \\
\hline kappa & $0.41^{* *}$ & $0.52^{* * *}$ & $0.50^{* * *}$ & $0.45^{* * *}$ & $0.64^{* * *}$ & $0.70^{* * *}$ & $0.22^{\mathrm{ns}}$ \\
\hline
\end{tabular}

Symbols ${ }^{* *}$ indicate correlation significant at $\mathrm{P}<0.01,{ }^{* * *}$ significant at $\mathrm{P}<0.001,{ }^{\mathrm{ns}}$ not significant
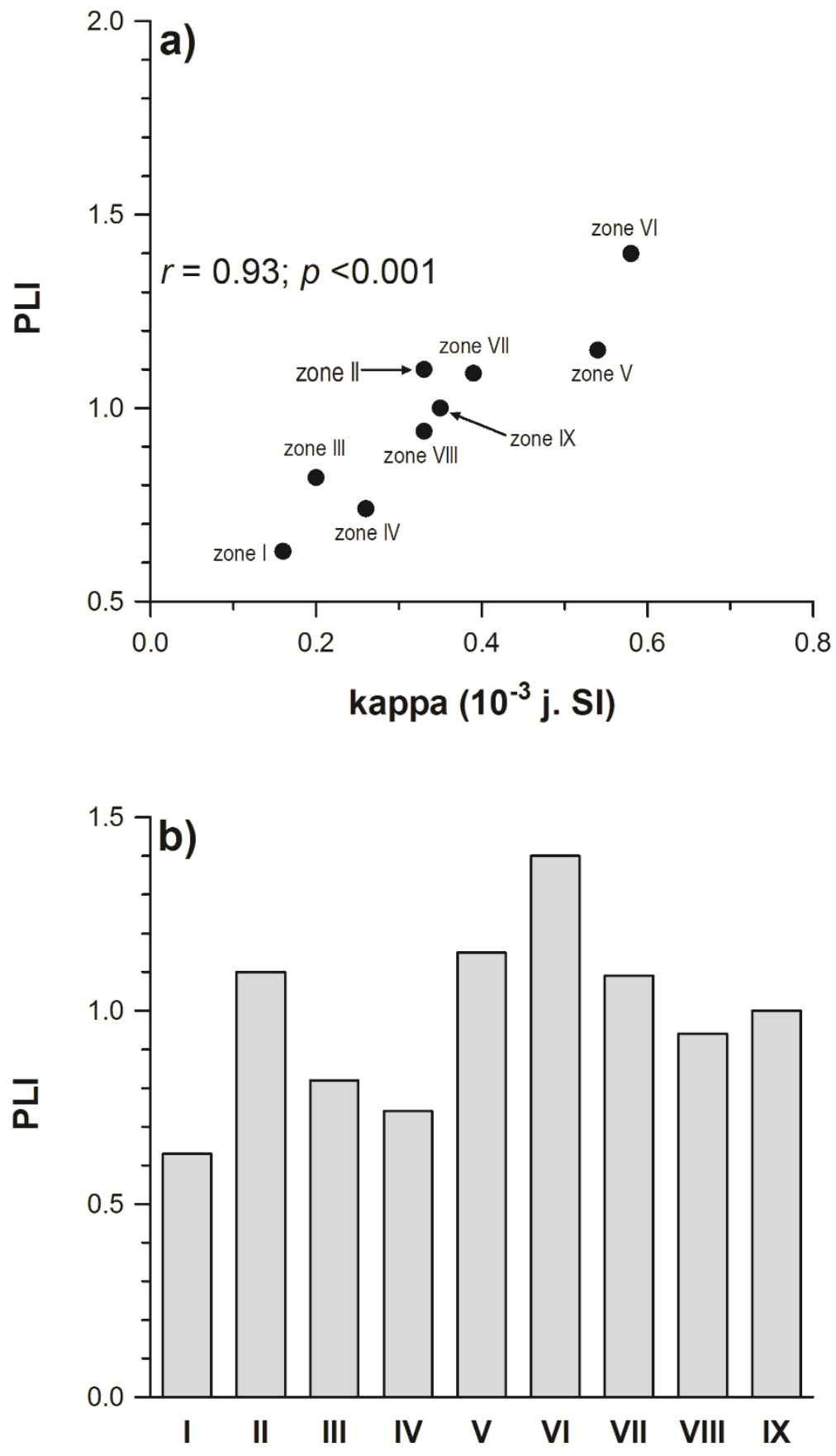

Fig. 3: a) Relationship between the mean values of magnetic susceptibility (kappa) and the values of Tomlinson pollution load index (PLI) for soils of the selected zones and b) mean values of PLI for soil samples in individual zones 


\section{CONCLUSION}

This work showed that concentrations of PTMs (As, $\mathrm{Cd}, \mathrm{Cu}, \mathrm{Hg}, \mathrm{Pb}, \mathrm{Zn}$ and $\mathrm{Fe}$ ) and magnetic susceptibilities in surface soils can change significantly along the urban - rural gradient in Bratislava city. Elevated concentrations of PTMs, mainly $\mathrm{Hg}, \mathrm{Pb}$ and $\mathrm{Zn}$, and higher values of magnetic susceptibility were found in the soils of highly urbanized areas of Bratislava city and they decrease with increasing distance from the city centre and adjacent sites. The enrichment of surface soils in PTMs in wider surrounding of the city centre is due to long-term urbanization and industrialization of these areas. Strongly significant correlation between Tomlinson pollution load index (PLI) and magnetic susceptibility values was found for soils polluted by PTMs. This type of correlation indicated the possibility of using magnetic measurements for simple and rapid indication of surface soil enrichment with potentially toxic metals. Therefore, the determination of magnetic susceptibility in soils can serve as an efficient "preliminary screening" method for the optimal selection of soil sampling sites and replace frequently used expensive and labour chemical analyses. From this reason, mapping of magnetic susceptibility of surface soils may also be used as a rapid method for the determination of the effect of urbanization on the pollution status of soils in relatively large areas.

\section{ACKNOWLEDGEMENTS}

This work was financially supported by the grants VEGA No. 1/0038/14 and UK/130/2015.

\section{REFERENCES}

Alloway B. J. 1990. Heavy metal in soils. Blackie and Son Ltd., Glasgow and London, 339 p.

Blundell A., Hannam J. A., Dearing J. A. \& Boyle J. F. 2009. Detecting atmospheric pollution in surface soils using magnetic measurements: A reappraisal using an England and Wales database. Environ. Pollut. 157: 2878-2890.

BRANDAU A. \& URbat M. 2000. Rock magnetic signature of sediment near the active Dead Dog Mound, Juan De Fuca Ridge. XXV EGS General Assembly, Geophysical Research Abstract, vol. 2, CD Rom.

ČURLíK J. \& ŠEFČíK P. 1999. Geochemical atlas of Slovak Republic. Part V - Soils. Soil Science and Conservation Research Institute, Bratislava.

Čurlík J. \& JuRKoviČ L'. 2012. Pedogeochémia. Univerzita Komenského v Bratislave, Bratislava, 228 p.

D’Emilio M., Chianese D., Coppola R., Macchiato M. \& Ragosta M. 2007. Magnetic susceptibility measurements as proxy method to monitor soil pollution: Development of experimental protocols for field survey. Environ. Monitor. Assess. 125: 137-146.

ĎURŽA O. 1999. Heavy metals contamination and magnetic susceptibility in soils around metallurgical plant. Phys. Chem. Earth (A) 24: 541-543.

ĎURŽA O. \& DLAPA P. 2009. Magnetic susceptibility record of loess/paleosol sequence: Case study from southwest Slovakia. Contrib. Geophys. Geodesy 39: 83-94.

ĎurŽA O., HiLler E., LACHKÁ L. \& TÓTH R. 2013. Magnetická susceptibilita a znečistenie pôd v areáloch materských škôlok Bratislavy potenciálne toxickými prvkami (Slovensko). Acta Geol. Slov. 5: 155-162.

El Baghdadi M., BARAKAT A., SAJIEdDine M. \& NADEM S. 2012. Heavy metal pollution and soil magnetic susceptibility in urban soil of Beni Mellal City (Morocco). Environ. Earth Sci. 66: 141-155.

FLANDERS P. J. 1994. Collection, measurements, and analysis of airborne magnetic particulates from pollution in the environment. J. Appl. Phys. 75: 5931-5936.

HANESCH M. \& SCHOLGER R. 2005. The influence of soil type on the magnetic susceptibility measured throughout soil profiles. Geophys. J. Int. 161: 50-56.

Hiller E., LACHKÁ L., JURKOVIČ L. \& VOZÁR J. 2015. Polycyclic aromatic hydrocarbons in urban soils from kindergartens and playgrounds in Bratislava, the capital city of Slovakia. Environ. Earth Sci. 73: 7147-7156.

HU X. F., SU Y., YE R., Li X. Q. \& ZHANG G. L. 2007. Magnetic properties of the urban soils in Shanghai and their environmental implications. Catena 70: 428-436. 
Chaparro M. A. E., Chaparro M. A. E., Marinelli C. \& Sinito A. M. 2008. Multivariate techniques as alternative statistical tools applied to magnetic proxies for pollution: a case study from Argentina and Antarctica. Environ. Geol. 54: 365-371.

CHEN J. 2007. Rapid urbanization in China: A real challenge to soil protection and food security. Catena 69: 115.

KAPIČKA A., PETROVSKÝ E., FIALOVÁ H. \& PODRÁZSKÝ V. 2004. Využití magnetické susceptibility lesních půd pro mapování imisní zátěže v regionu KRNAP. In: Štursa J., Mazurski K.R., Palucki A. \& Potocka J. (Eds.): Geoekologické problémy Krkonoš. Szklarska Poreba. Opera Corcontica, 41, pp. 55-59.

Li X., Poom C. \& LIU P. S. 2001. Heavy metal contamination of urban soils and street dusts in Hong Kong. Appl. Geochem. 16: 1361-1368.

LIU D., MA J., SUN Y. \& LI Y. 2016. Spatial distribution of soil magnetic susceptibility and correlation with heavy metal pollution in Kaifeng City, China. Catena 139: 53-60.

LJUNG K., Selinus O. \& OTABbong E. 2006. Metals in soils of children's urban environments in the small northern European city of Uppsala. Sci. Total Environ. 366: 749-759.

LU S. G. \& BAI S. Q. 2006. Study on the correlation of magnetic properties and heavy metals content in urban soils of Hangzhou City, China. J. Appl. Geophys. 60: 1-12.

LU S. G., BAI S. Q. \& FU L. X. 2008. Magnetic properties as indicator of $\mathrm{Cu}$ and Zn contamination in soils. Pedosphere 18: 479-485.

LU S. G., WANG H. Y. \& BAI S. Q. 2009. Heavy metal content and magnetic susceptibility of soils along an urban-rural gradient in rapidly growing city of eastern China. Environ. Monitor. Assess. 155: 91-101.

LU S. G., WANG H. Y. \& GUO J. L. 2011. Magnetic enhancement of urban roadside soils as a proxy of degree of pollution by traffic-related activities. Environ. Earth Sci. 64: 359-371.

MAGIERA T. \& STRZYSZCZ Z. 2000. Ferrimagnetic minerals of anthropogenic origin in soils of polish national parks. Water Air Soil Pollut. 124: 37-48.

MAHER B. A., Moore C. \& MATZKA J. 2008. Spatial variation in vehicle-derived metal pollution identified by magnetic and elemental analysis of roadside tree leaves. Atmos. Environ. 42: 364-373.

MALOVCOVÁ E. 2014. Využitie pôdnej magnetometrie pri štúdiu kontaminácie urbánnych pôd potenciálne toxickými stopovými prvkami (príklad Bratislavy). Manuskript, PriF UK Bratislava, $82 \mathrm{~s}$.

MAZÚR E. \& LUKNIŠ M. 1980. Regionálne geomorfologické členenie SSR 1:500 000. Atlas SSR. Geografický ústav SAV, Bratislava.

Menichini E., IAcovella N., Monfredini F. \& Turrio-Baldassarri L. 2007. Atmospheric pollution by PAHs, PCDD/Fs and PCBs simultaneously collected at a regional background site in central Italy and at an urban site in Rome. Chemosphere 69: 422-434.

MiKLAJEV J. V. \& KUDRJAVCEV JU. I. 1982. Izučenije magnitnoj vosprijimčivosti počv primenitel'no k zadačam geologičeskogo kartirovanija. Vest. Leningr. Universit. 18: 79-84.

MIKLAJEV J. V. \& ŽoGOLEV S. L. 1990. O prostranstvennoj svjazi anomalij magnitnoj vosprijimčivosti počv s litogeochemičeskimi oreolami rudnych elementov. Vest. Leningr. Universit. 7: 26-33.

MiLIČKA J., VASS D. \& PERESZLÉNYI M. 2002. Organická hmota v neskoromiocénnych sedimentoch Lučeneckej kotliny, južné Slovensko. Miner. Slov. 34: 93-98.

Morton-Bermea O., Hernandez E., Martinez-Pichardo E., Soler-Arechalde A. M., Lozano SantaCruz R., Gonzalez-Hernandez G., Beramendi-Orosco L. \& Urrutia-Fucugauchi J. 2009. Mexico City topsoils: Heavy metals vs. magnetic susceptibility. Geoderma 151: 121-125.

MurÁNSZKY G., ÓVÁRI M., VIRÁG I., CSIBA P., DOBAI R. \& ZÁRAY G. 2011. Chemical characterization of PM 10 fractions of urban aerosol. Microchem. J. 98: 1-10.

NG S. L., CHAn L. S., LAM K. C. \& CHAN W. K. 2003. Heavy metal contents and magnetic properties of playground dust in Hong Kong. Environ. Monitor. Assess. 89: 221-232.

NORRA S. \& STUBEN D. 2003. Urban soils. J. Soil. Sediment. 3: 230-233.

ORgEIRA J. M., EGLI R. \& COMPAGNUCCI H. R. 2011. A quantitative model of magnetic enhancement in loessic soils. In: Petrovský E., Herrero-Bervera E., Harinarayana T. et al. (eds.): Earth's Magnetic Interior. Book Series: IAGA Special Sopron Book Series, 1, pp. 361-397.

PetrovskÝ E., KAPIČKA A., JordANOVA N., KnAB M. \& HofFMAnN V. 2000. Lowfield magnetic susceptibility: a proxy method of estimating increased pollution of different environmental systems. Environ. Geol. 39: 312318. 
RoBertson D. J., TAYLOR K. G. \& HoOn S. R. 2003. Geochemical and mineral magnetic characterisation of urban sediment particulates. Manchester, UK. Appl. Geochem. 18: 269-282.

Shilton V. F., Boоth C. A., Smith J. P., Giess P., Mitchell D. J. \& Williams C. D. 2005. Magnetic properties of urban street dust and their relationship with organic matter content in the West Midlands, UK. Atmos. Environ. 39: 3651-3659.

SCHMidT A., YARnOld R., Hill M. \& ASHMORE M. 2005. Magnetic susceptibility as proxy for heavy metal pollution: A site study. J. Geochem. Explor. 85: 109-117.

SimOn E., Vidic A., BRAUn M., FÁBiÁN I. \& TóTHMÉRÉSZ B. 2013. Trace element concentrations in soils along urbanization gradients in the city of Wien, Austria. Environ. Sci. Pollut. Res. 20: 917-924.

SobockÁ J., JAĎUĎA M., RUŽEKOVÁ-PoltÁRSKA K. \& ŠURINA B. 2007. Urbánne pôdy (Príklad Bratislavy). Výskumný ústav pôdoznalectva a ochrany pôdy, Bratislava, $174 \mathrm{~s}$.

SPITERi C., KALINSKI V., RosLER W., HOFFMANN V. \& APPEL E. 2005. Magnetic screening of a pollution hotspot in the Lausitz area, Eastern Germany: correlation analysis between magnetic proxies and heavy metal contamination in soils. Environ. Geol. 49: 1-9.

TAN J.-H., Bi X.-H., DuAn J.-C., RAhN K.A., ShEnG G.-Y. \& FU J.-M. 2006. Seasonal variation of particulate polycyclic aromatic hydrocarbons associated with $\mathrm{PM}_{10}$ in Guangzhou, China. Atmos. Res. 80: 250-262.

TOMLinson D. L., Wilson J. G., HARris C. R. \& JEFFneY D. W. 1980. Problems in the assessment of heavy metal levels in estuaries and the formation of a pollution index. Helgoländer Wissenschaftliche Meeresuntersuchungen 33: 566-572.

VADJUnINA A. F. \& BABANIN V. F. 1972. Magnitnaja vosprijimčivost' nekotorych počv SSSR. Počvovedenije 10: 55-66.

WAGROWSKI D. M. \& Hites R. 1997. PAH accumulation in urban, suburban and rural vegetation. Environ. Sci. Technol. 31: 279-282.

WONG F., HARner T., LiU Q. T. \& DiAMOND M. L. 2004. Using experimental and forest soils to investigate the uptake of polycyclic aromatic hydrocarbons (PAHs) along an urban-rural gradient. Environ. Pollut. 129: $387-$ 398.

YANG P., YANG M. \& SHAO H. 2012. Magnetic susceptibility and heavy metals distribution from risk-cultivated soil around the iron-steel plant, China. Clean - Soil Air Water 40: 615-618.

YANG P., YANG M., MAO R. Z., YANG P., YANG M. \& BYRUE J. M. 2015. Impact of long-term irrigation with treated sewage on soil magnetic susceptibility and organic matter content in North China. Bull. Environ. Contam. Toxicol. 95: 102-107.

ZHU W. X. \& CARREIRO M. M. 2004. Variations of soluble organic nitrogen and microbial nitrogen in deciduous forest soils along an urban-rural gradient. Soil Biol. Biochem. 36: 279-288. 